УAK 005.336.6:659

\title{
О. О. Корчинська,
}

к. е. н., старший викладач кафедри адміністративного та фінансового менеАжменту, Національний університет " $\Lambda$ ьвівська політехніка"

ORCID ID: 0000-0003-0028-1853

DOI: $10.32702 / 2306-6792.2019 .10 .46$

\section{ОКРЕМІ АСПЕКТИ УПРАВЛІННЯ КОРПОРАТИВНИМ ІМІАЖЕМ ПІАПРИЕМСТВА}

\author{
O. Korchynska, \\ $\mathrm{PhD}$ in Economics, senior lecture of Administrative and Financial Management Department, \\ Lviv Polytechnic National University
}

SEPARATE ASPECTS OF CORPORATE IMAGE MANAGEMENT

У статті досліджено сутність дефініції "корпоративний імідж підприємства". Продемонстровано модель впливу позитивного корпоративного іміджу організації на процес їі діяльності та результати. Визначено, що імідж підприємства підАається впливу чинникам зовнішнього та внутрішнього середовища. Проведене дослідження показало, що корпоративний іміАж складається з іміджу керівника, іміджу персоналу, іміАжу товару чи послуги, іміАжу покупця, внутрішнього іміджу тощо. На основі результатів проведеного аналізу виявлено, що головною умовою ефективного управління та удосконалення корпоративного іміджу підприємства є своєчасність виявлення перешкод подальшого розвитку підприємства. У процесі побудови системи заходів підвищення корпоративного іміджу важливо визначити затрати на них та очікувану вигоду від запровадження таких заходів. Варто також наголосити на важливості участі підприємства у різноманітних заходах, враховуючи специфіку його діяльності, 3 метою налагодження контактів 3 потенційними клієнтами, постачальниками, а також з ознайомленням роботи конкурентів та вивченні тенденцій розвитку ринкового середовища (не менше 100 слів).

The article states that among the set of many factors that influence the corporate image of the enterprise, the question of determining the readiness and ability of the enterprise to its formation is very important. It was investigated that the subjects or carriers of the corporate image can be absolutely everyone, that is, who and that is able to distribute information at the enterprise level and beyond: various categories of personal, public organizations, as well as those from whom the "social order" goes.

The article presents the structure of corporate image and the description of each of its elements.

In the process of analyzing the corporate image of the enterprise it is established that scientific researches are based on the use of philosophical (fundamental), general and concrete scientific principles, systems of general scientific and special methods and techniques. Taking into account the number of scientific researches and despite the diversity of scientific opinions about the corporate image of the enterprise and its components, it has been discovered that the company, its products and employees, the culture of communication in the middle of the team and the way of communication with clients are common to all.

Analyzing the influence of the state on the formation of a high level of competitiveness of the national economy, the image of the nation as a vector of constituent corporate image of the enterprise, the sector of the economy and the state of demand in the country are also considered. The interaction of these components determines the level of the possibility of forming and maintaining an appropriate level of corporate image of the enterprise. It is determined that corporate image is the most effective way of presenting information about an enterprise in this context as it is beneficial for it to achieve its goals. Therefore, the technology of forming an image of an enterprise must take into account certain factors. 
It was also revealed that the top controversy and the reasons hindering business development are such as imperfect legislation and often changing rules; excessive taxes; lack of funding sources; unequal opportunities in terms of competition with a large-scale firms; comprehensive corruption; lack of support, and thus obstacles on the part of the state (its bodies); underdeveloped infrastructure (banking and communications security systems); professional unpreparedness of entrepreneurs themselves. This can be accompanied by economic depression, inflation and the absence of a solid national monetary unit recently, affecting not only small businesses, but also other economic actors, as an inevitable accompaniment to the transition period.

Ключові слова: імідж підприємства, корпоративний імідж підприємства, прочес управління, зовнішне та внутрішне середовища підприємства, фактори впливу.

Key words: the image of the enterprise, the corporate image of the enterprise, the process of management, the external and internal environment of the enterprise, the factors of influence.

\section{ПОСТАНОВКА ПРОБЛЕМИ}

Вітчизняні підприємства задля отримання доступу до нових ринків збуту та задля залучення споживачів, змушені не лише відповідати на ключові три запитання економіки: "Що?", "Як?" та "Аля кого?". Фірми, які бажають досягнути успіху змушені прислухатись до навіювань ринку та реалізовувати заходи, пов'язані 3 формуванням та управлінням іміджем. Ускладнюється ситуація тим, що керівництво компанії основну мету їі діяльності вбачає лише у отриманні прибутку та його максимізації шляхом збільшення продажів. Натомість, забуваючи, що формування іміджу організації діє як найважливіший фактор зміцнення конкурентних позицій, сприяє успішній діяльності в довгостроковій перспективі.

\section{АНАЛІЗ ОСТАННІХ ДОСЛІДЖЕНЬ ТА ПУБЛІКАЦІЙ}

Проблема формування позитивної репутації спочатку окремої особи - управителя, а потім - підприємства зацікавила ще мудреців Стародавньої Греції. Серед найбільш відомих дослідників дефініції "корпоративний імідж" варто відзначити 3. Фройд, Ф. Котлер, Р. Брум, А. Сентер, О. Шаша., К. Анохіна, С. Афанасьєв, Р. Блекуелл, Б. Ажі, О. Філатова, М. Шишкіна, А. Сальникова, I. Альошина, Н. Аснович, А. Беленкова, І. Бердніков та інших.

\section{ПОСТАНОВКА ЗАВДАННЯ}

Метою статті $є$ дослідження особливостей формування позитивного корпоративного іміджу підприємства, управління ним, а також його вплив на результати діяльності господарюючого суб'єкта.

\section{ВИКЛАД ОСНОВНОГО МАТЕРІАЛУ}

Сучасне підприємство є самостійним культурним утворенням зі своїми цінностями, нор- мами, традиціями, ритуалами, героями, легендами тощо. Фірмовий стиль, імідж, організаційна культура, корпоративний дух є частиною сучасної парадигми менеджменту.

Імідж підприємства $є$ надзвичайно важдивим та впливовим фактором при виборі споживачем товару чи послуги відповідного підприємства. Імідж виступає посередником у спілкуванні з діловими партнерами, покупцями, працівниками та створюється шляхом цілеспрямованого стратегічного планування діяльності підприємства.

Поняття "імідж" (від лат. "Imago" - образ, відображення, зображення) має багато різних визначень. А. Петровський і М. Ярошевський у своєму "Короткому психологічному словнику" визначають імідж як "стереотипізований образ конретного об'єкта, що існує у масовій свідомості" [1, с. 28].

Маркетолог $Ф$. Котлер визначає імідж як "сприйняття компанії чи її товарів суспільством" [2, с. 237]. Спеціаліст у галузі менеджменту О. Віханський дає загальне визначення іміджу: "Імідж явища - це стійке уявлення про особливості, специфічні властивості і риси, які характерні для даного явища" [3, с. 207].

Ідентифікація організації на ринку може відбуватись з застосуванням різних ознак. Проте комплексна оцінка діяльності цієё організації грунтується на всебічному та глибокому підході, оскільки в основі цього лежать смаки та вподобання, насамперед, споживачів. Тобто імідж підприємства формується керівництвом та усіма працівниками шляхом задоволення потреб споживачів. Швидкі зміни смаків та вподобань споживачів, звичайно ускладнюють роботу підприємства та його керівництва зокрема, хоча для тих підприємств, в яких на ринку вже є сформований імідж, така ситуація не призводить до жодних ускладнень. 
Таблиця 1. Спектр підходів до розуміння іміджу підприємства

\begin{tabular}{|c|c|c|}
\hline № & Автор & Значення \\
\hline 1 & $\begin{array}{l}\text { А. К. Семенов } \\
{[4, \text { с. } 87]}\end{array}$ & $\begin{array}{l}\text { Це навмисно спроектований в інтересах фірми, оснований на } \\
\text { особливостях діяльності, внутрішніх закономірностях, } \\
\text { властивостях, достоїнствах, якостях і характеристиках образ, } \\
\text { який ціленаправлено входить у свідомість (підсвідомість) } \\
\text { цільової аудиторії, відповідає ії очікуванням і служить } \\
\text { відмінністю фірми від аналогічних }\end{array}$ \\
\hline 2 & $\begin{array}{l}\text { Л. Е. Орбан } \\
\text { Лембрик } \\
{[5, \text { с. } 543]} \\
\end{array}$ & $\begin{array}{l}\text { Це враження, яке організація та її працівники справляють на } \\
\text { людей і яке фіксується в їх свідомості у формі певних емоційно } \\
\text { забарвлених стереотипних уявлень (думок, суджень про них) }\end{array}$ \\
\hline 3 & $\begin{array}{l}\text { В. О. Сизоненко } \\
{[6, \text { с. } 420]}\end{array}$ & $\begin{array}{l}\text { Це позитивний образ будь'якої фірми, що формує стабільну } \\
\text { конкурентну перевагу через створення загального образу, } \\
\text { репутації, думки громадськості,споживачів і партнерів про } \\
\text { престиж підприємства, його товари та послуги, післяпродажний } \\
\text { сервіс }\end{array}$ \\
\hline 4 & $\begin{array}{l}\text { Ю. Бабік } \\
{[7, \text { с. 123] }}\end{array}$ & $\begin{array}{l}\text { Це фактор довіри споживачів до організації і їі товару, фактор } \\
\text { зростання числа продажів, а значить, фактор процвітання або } \\
\text { занепаду для організації, їі власників і ії працівників }\end{array}$ \\
\hline 5 & $\begin{array}{l}\text { В. Абаренков } \\
{[8, \text { с. 289] }}\end{array}$ & $\begin{array}{l}\text { В широкому розумінні - поширення уявлення щодо характеру } \\
\text { того або іншого об'єкта; у більш вузькому (стосовно пропаганди, } \\
\text { реклами) означає цілеспрямовано сформований образ-уявлення, } \\
\text { який за допомогою асоціацій наділяє об'єкт (явище, особистість, } \\
\text { товар тощо) додатковими цінностями (соціальними, політичними, } \\
\text { соціально-психологічними, естетичними тощо) та завдяки цьому } \\
\text { сприяє більш цілеспрямованому та емоційному сприйманню }\end{array}$ \\
\hline 6 & Д. Доті [9, с. 93] & $\begin{array}{l}\text { Це все і всі, хто має хоч якесь відношення до компанії і } \\
\text { пропонованих нею товарів і послуг; це витвір, що постійно } \\
\text { створюється як словами, так і образами, які химерно } \\
\text { перемішуються і перетворюються в єдиний комплекс }\end{array}$ \\
\hline 7 & $\begin{array}{l}\text { О.В. Согачова } \\
{[10, \text { с. } 87]}\end{array}$ & $\begin{array}{l}\text { Це навмисне спроектований в інтересах підприємства, що } \\
\text { грунтується на особливостях діяльності, внутрішніх } \\
\text { закономірностях, властивостях, перевагах, якостях і } \\
\text { характеристиках образу, який входить у свідомість } \\
\text { (підсвідомість) цільової аудиторії, відповідає їі очікуванням і } \\
\text { відрізняє компанію від аналогічних }\end{array}$ \\
\hline 8 & $\begin{array}{l}\text { В.Никифоренко, } \\
\text { В. Кравченко } \\
{[11]}\end{array}$ & $\begin{array}{l}\text { Це сприйняття індивідуальності підприємства, усвідомлення його } \\
\text { специфічних рис, особливостей у свідомості як споживачів, так і } \\
\text { конкурентів та інших громадських груп }\end{array}$ \\
\hline 9 & $\begin{array}{l}\text { Вебстер } \\
{[12, \text { с. } 205]}\end{array}$ & $\begin{array}{l}\text { Це штучне створення неперевершеного образу. Імідж - це штучна } \\
\text { імітація або подання зовнішньої форми будь-якого об'єкта, } \\
\text { держави, політика, організації }\end{array}$ \\
\hline 10 & Г. Почепцов [13] & $\begin{array}{l}\text { Це найбільш економний спосіб породження і розпізнавання } \\
\text { складної соціальної дійсності як результат обробки інформації, як } \\
\text { згорнутий текст, як комунікативну одиницю, за допомогою якої } \\
\text { можна працювати з масовою свідомістю }\end{array}$ \\
\hline
\end{tabular}

Існує багато наукових праць та підходів щодо визначення суті "імідж підприємства", тому в таблиці 1 наведемо окремі 3 них.

Поняття "імідж організації" включає в себе дві складові: описову (або інформаційну), яка відображає образ організації; оцінну, яка існує тому, що будь-яка інформація про організацію спонукає в суспільстві (суспільній свідомості) оцінки, емоції, які можуть володіти різною інтенсивністю, можуть сприйматись або відкидатись.

Загалом, результат "роботи" іміджу підприємства можна схематично зобразити так (див. рис. 1).
Формуватися імідж підприємства починає одразу ж, як тільки воно виходить на ринок. Цей процес може мати дві форми реалізації: цілеспрямоване формування іміджу шляхом залучення знань керівництва, часу та коштів, та стихійно - керівництво фірми не приділяє цьому жодної уваги. Варто також наголосити на тому, що в момент, коли керівництво компанії задається питанням: "А чим ми відрізняємось від конкурентів?" якраз і починає формуватись $11 ̈$ імідж.

Імідж підприємства, будучи соціально-психологічним феноменом, стосується діяльності будь-якого підприємства [5, с. 87].

Попри різноманітність підходів та трактувань сутності іміджу, тобто "корпоративного іміджу підприємства", варто узагальнити та виділити основні його характеристики. Корпоративний імідж підприємства має насамперед:

- бути орієнтованим на цільову аудиторію (потенційних споживачів);

- відображати їхні смаки та вподобання в певний період часу;

- психологічну (символічну) природу, тобто певні уявлення та стереотипи про конкретну орга-

нізацію;

- бути гнучким до змін в ринковому середовищі, з одного боку, та постійним у своїх переконаннях - 3 іншого боку;

- поєднувати зовнішні та внутрішні фактори впливу при його формуванні [6, с. 102].

Процес формування корпоративного іміджу будь-якого підприємства не відбувається сам по собі, а забезпечується шляхом використання певних засобів. Загальні характеристики засобів створення корпоративного іміджу наведено в таблиці 2.

Управління корпоративним іміджем підприємства виражається у формі співвідношен-

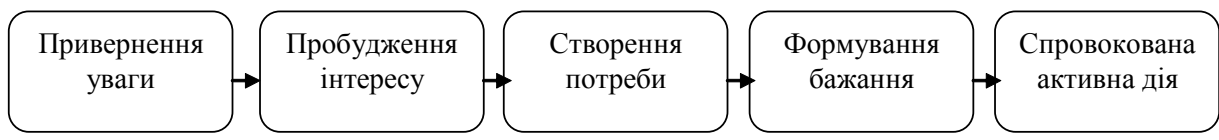

Рис. 1. Модель демонстрації "роботи" іміджу

Ажерело: укладено за матеріалами [4, с. 61]. 
Таблиця 2. Характеристика засобів створення корпоративного іміджу

\begin{tabular}{|l|l|}
\hline \multicolumn{1}{|c|}{$\begin{array}{c}\text { Засоби } \\
\text { створення }\end{array}$} & \multicolumn{1}{c|}{ Інструменти } \\
\hline $\begin{array}{l}\text { Візуальні } \\
\text { засоби }\end{array}$ & $\begin{array}{l}\text { Оформлення вітрин, виставок, розробка макетів оголошень, } \\
\text { упаковок товару, інтер'єр офісів, магазинів, шоурумів, дизайн } \\
\text { форменного одягу для працівників підприємства, тобто } \\
\text { різного роду дизайнерські прийоми }\end{array}$ \\
\hline $\begin{array}{l}\text { Вербальні } \\
\text { засоби }\end{array}$ & $\begin{array}{l}\text { Навчання працівників правильно та ввічливо спілкуватися } 3 \\
\text { клієнтами, розробка лозунгу підприємства }\end{array}$ \\
\hline $\begin{array}{l}\text { Рекламні } \\
\text { засоби }\end{array}$ & $\begin{array}{l}\text { Використання всіх можливих та доступних рекламних } \\
\text { потоків (ЗМI) для донесення інформації споживачам у } \\
\text { неперекрученому вигляді }\end{array}$ \\
\hline РR-заходи & $\begin{array}{l}\text { Організація та проведення різноманітних івент-заходів, } \\
\text { презентацій, конференцій, благодійних вечірок і т.д. }\end{array}$ \\
\hline
\end{tabular}

ня ціни і якості товару. Ао цих двох складових додаються додаткові, пов'язані з оновленням продукції, що випускається, сервісом, тривалістю гарантійного обслуговування, наявністю достатньої кількості сервісних центрів.

Процес оцінки управління корпоративним іміджем підприємства повинен спиратися на всебічне вивчення характеристик товарів, різноманіття яких вимагає різних методів оцінки їх конкурентоспроможності.

При створенні системи управління корпоративним іміджем підприємства враховується можливість прогнозування конкурентоспроможності товару, послуги в майбутньому на максимально можливо тривалий термін з метою створення конкурентних переваг товарів і послуг. Узагальнену інформацію про підходи управління корпоративним іміджем підприємства подано в таблиці 3.

Запропоновані науковцями підходи щодо управління корпоративним іміджем підприємства охоплюють основні напрями та сфери діяльності підприємства, проте не враховують етапи та рівень розвитку самого підприємства, а отже, і його іміджу.

Таким чином, ми вважаємо, що управління корпоративним іміджем підприємства повинно грунтуватись та орієнтуватись на етап життєвого циклу підприємства та на інформацію щодо пріоритетів розвитку його подальшої діяльності. В залежності від цього, керівництво підприємства буде обирати ті заходи іміджевої політики, які є найбільш прийнятними для конкретної ситуації та умов господарювання.

Управління корпоративним іміджем підприємства водночас залежить від становища підприємства на ринку і комплексу економічних умов його функціонування. Сучасні процеси вказують на загострення питань стосовно рівня втручання держави при створенні найбільш сприятливого середовища для національних суб'єктів.

Таблиця 3. Підходи до управління корпоративним іміджем підприємства

\begin{tabular}{|c|c|c|c|}
\hline \multirow{2}{*}{ Підхід } & \multirow{2}{*}{ Сутність } & \multicolumn{2}{|c|}{ Характеристика } \\
\hline & & позитивна & негативна \\
\hline 1 & 2 & 3 & 4 \\
\hline Виробничий & $\begin{array}{l}\text { Акцент на якість } \\
\text { продукції, соціальна } \\
\text { відповідальність, } \\
\text { турбота про } \\
\text { споживачів та } \\
\text { клієнтів }\end{array}$ & $\begin{array}{l}\text { Інвестицій та підвищення } \\
\text { економічної ефективності } \\
\text { виробництва; заходи } 3 \\
\text { професійного розвитку } \\
\text { персоналу; постійне } \\
\text { підвищення якості продукції }\end{array}$ & $\begin{array}{l}\text { Незначна увага до } \\
\text { формування } \\
\text { корпоративної культури } \\
\text { та створенню } \\
\text { внутрішнього іміджу } \\
\text { компанії; недооцінка } \\
\text { важливості } \\
\text { використання 3МІ та } \\
\text { роботи з контактними } \\
\text { аудиторіями }\end{array}$ \\
\hline Комунікаційний & $\begin{array}{l}\text { Ядро } \\
\text { «маркетингових» } \\
\text { програм складають } \\
\text { заходи } 3 \text { планування } \\
\text { конкурентної } \\
\text { боротьби, } \\
\text { просуванню } \\
\text { продажів, } \\
\text { проведення PR- } \\
\text { кампаній }\end{array}$ & $\begin{array}{l}\text { Встановлення оптимальної } \\
\text { цінової політики та } \\
\text { налагодження стійких } \\
\text { зв'язків зі споживачами } \\
\text { продукції; проведення } \\
\text { маркетингових досліджень, } \\
\text { інтенсивних рекламних } \\
\text { кампаній, PR-акцій, } \\
\text { спрямованих на формування } \\
\text { емоційного іміджу }\end{array}$ & $\begin{array}{l}\text { Рідко використовуються } \\
\text { заходи, спрямовані на } \\
\text { формування іміджу } \\
\text { персоналу та керів- } \\
\text { ництва підприємства; } \\
\text { побудова іміджу } \\
\text { організації майже цілком } \\
\text { зводиться до } \\
\text { формування іміджу } \\
\text { товару }\end{array}$ \\
\hline Клієнтський & $\begin{array}{l}\text { Формування певної } \\
\text { культури } \\
\text { взаємовідносин } 3 \\
\text { клієнтами та } \\
\text { партнерами, } \\
\text { налагодження } \\
\text { зворотного зв'язку }\end{array}$ & $\begin{array}{l}\text { Диференціація заходів } \\
\text { налагодження зв'язку із } \\
\text { зовнішнім середовищем } \\
\text { підприємства; упровадження } \\
\text { сервісного обслуговування }\end{array}$ & $\begin{array}{l}\text { Рідко використовуються } \\
\text { заходи з формування } \\
\text { внутрішнього іміджу }\end{array}$ \\
\hline Кадровий & $\begin{array}{l}\text { Заходи, спрямовані } \\
\text { на формування } \\
\text { внутрішнього } \\
\text { іміджу }\end{array}$ & $\begin{array}{l}\text { Використання засобів } \\
\text { стимулювання виробничого } \\
\text { процесу, мотивації персоналу } \\
\text { і забезпечення соціальних } \\
\text { гарантій }\end{array}$ & $\begin{array}{l}\text { Недостатнє } \\
\text { використання засобів } \\
\text { формування зовнішнього } \\
\text { іміджу підприємства }\end{array}$ \\
\hline
\end{tabular}

Ажерело: сформовано на основі [7-9]. 


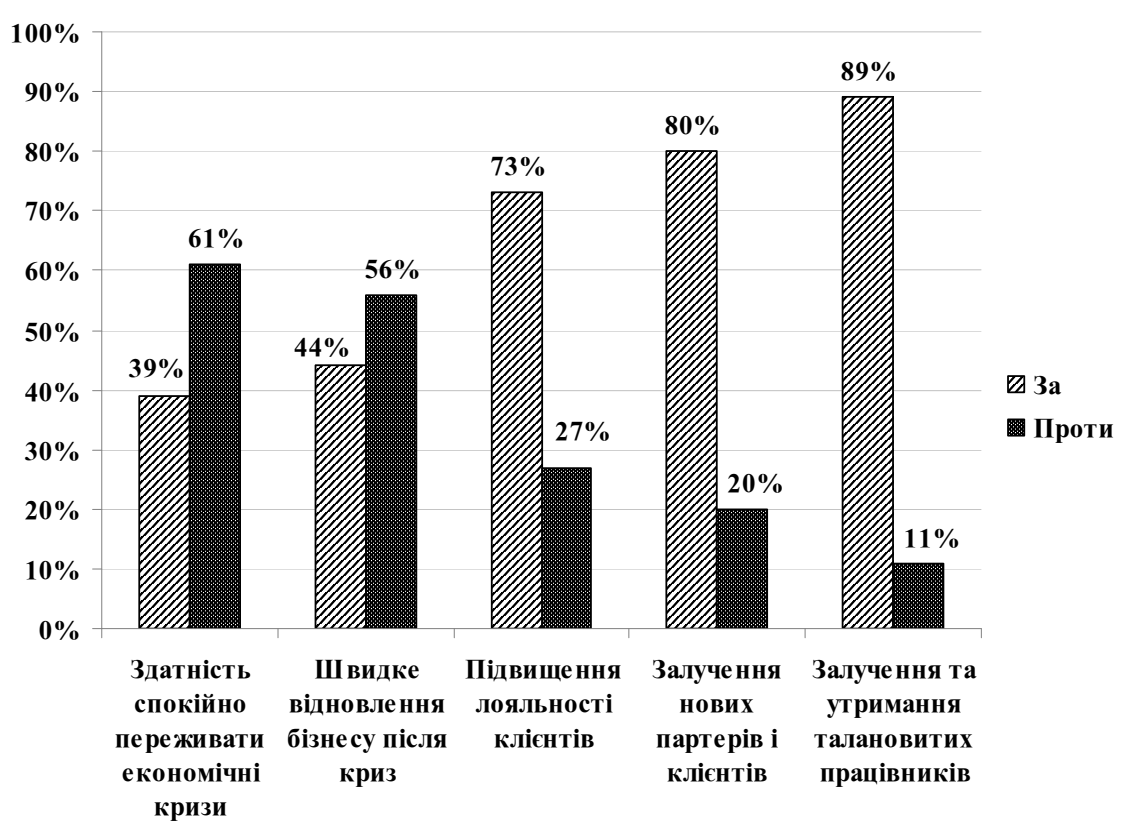

Рис. 2. Переваги управління корпоративним іміджем

Ажерело: укладено за матеріалами [14, с. 39].

Процес управління корпоративним іміджем підприємства піддається впливу факторів, які є змінними. Тому суб'єкти підприємницької діяльності, прагнучи покращити показники своєї діяльності, в тому числі і за рахунок позитивного корпоративного іміджу, мають змогу впливати на ці фактори, передбачати дію окремих 3 них та готуватися до реагування. Таким чином, головним фактором впливу $є$ час.
Корпоративний імідж підприємства не формується автоматично, а залежить від особистих якостей керівника, навик та вмінь працівників, а з іншого боку, суттевий вплив на нього чинять культурні та ментальні орієнтації споживачів. Аержава як безпосередній учасник економічних відносин формує середовище, в якому підприємства мають змогу розвиватись у різних напрямах.

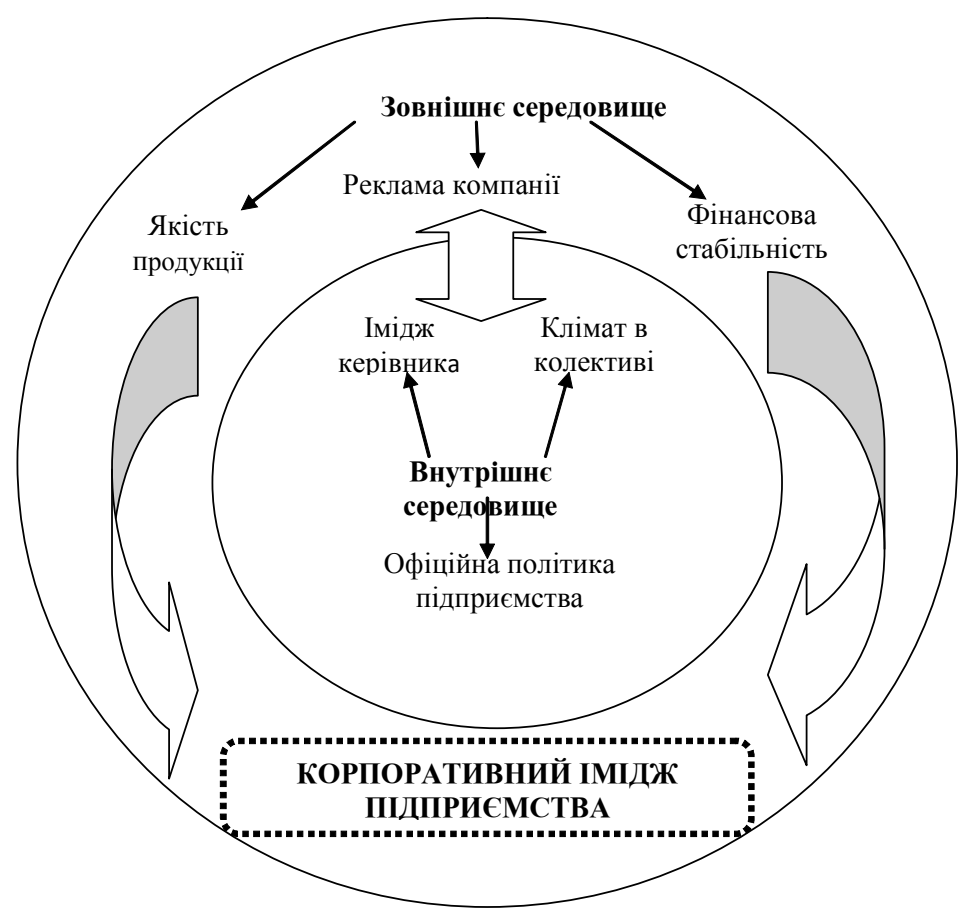

Рис. 3. Взаємозв'язок елементів внутрішнього та зовнішнього середовища та іх вплив на корпоративний імідж підприємства 
Таблиця 4. Фактори та напрями удосконалення корпоративного іміджу підприємства

\begin{tabular}{|c|c|c|}
\hline \multicolumn{3}{|c|}{ Корпоративний імідж підприємства } \\
\hline Імідж персоналу & $\begin{array}{c}\text { Імідж виробництва (виконання } \\
\text { електромонтажних робіт) }\end{array}$ & Імідж керівника \\
\hline $\begin{array}{l}\text { - Покращення умов } \\
\text { праці. } \\
\text { - Підвищення } \\
\text { кваліфікації персоналу. } \\
\text { - Надання стимулів. } \\
\text { - Створення } \\
\text { сприятливого } \\
\text { психологічного клімату }\end{array}$ & $\begin{array}{l}\text { - Використання прогресивних } \\
\text { технологій. } \\
\text { - Оновлення фондів. } \\
\text { - Впровадження інноваційної } \\
\text { політики у виробництво. } \\
\text { - Проведення науково-дослідних } \\
\text { та конструкторських робіт }\end{array}$ & $\begin{array}{l}\text { - Участь керівника в семінарах та } \\
\text { навчаннях щодо електромонтажних } \\
\text { робіт. } \\
\text { - Відвідування керівником об'єктів } \\
\text { роботи з метою безпосереднього } \\
\text { спілкування з замовниками та } \\
\text { контроль з роботою працівників. } \\
\text { - Керівник - формальний та } \\
\text { неформальний лідер в організації }\end{array}$ \\
\hline
\end{tabular}

Тобто з позицій функціонально-структурного підходу це дає змогу розглядати корпоративний імідж підприємства одночасно і елементом системи, і окремою системою [10].

Варто також взяти до уваги, що за даними глобального дослідження Інституту репутації (project Global Pulse), визначальними чинниками, що впливають на репутацію компанії серед громадськості, вважаються: якість продуктів і послуг, якість корпоративного управління і корпоративна соціальна відповідальність [8, c. 40].

Сильне становище фірми на ринку прирівнюється до сильного корпоративного іміджу, який стає необхідною умовою досягнення фірмою стійкого та тривалого ділового успіху і цьому є цілком логічне пояснення [2, с. 26]. По-перше, він дає ефект придбання організацією визнаної ринкової сили, тому що сприяє зниженню чутливості до цін, подруге, підвищує специфічність та унікальність товарів, а це означає, що він захищає організацію від атак конкурентів і зміцнює позиції щодо товарів-замінників. I, по-третє, він полегшує доступ фірми до різних ресурсів: фінансових, інформаційних, людсьКИх тощо.

За даними опитування, проведеного компанією Burson Marsteller, системне управління корпоративним іміджем компанії дає переваги, які показано на рисунку 2.

Як бачимо з рисунка, управління корпоративним іміджем сприяє розширенню діяльності підприємства, залученню висококваліфікованих працівників, мінімізовує вплив та наслідки кризових ситуацій, формує коло постійних клієнтів.

Оцінка корпоративного іміджу підприємства є з'єднуючою ланкою між стадією економічного аналізу та стадією прийняття управлінських рішень. Корпоративний імідж підприємства залежить від об'єкта порівняння, а також факторів, які використовуються для його оцінки [5].
Сильний імідж організації і її товарів говорить про унікальні ділові здібності, які дозволяють підвищувати пропоновану споживачам цінність товарів і послуг. Тому вплив факторів зовнішнього та внутрішнього середовища на формування та управління корпоративним іміджем можна схематично зобразити так (див. рис. 3).

Корпоративний імідж підприємства - це відносне поняття, яке відображає відмінність процесу розвитку цього підприємства від конкурента, як за ступенем задоволення його продукцією суспільних потреб, так і за ефективністю комерційної діяльності.

На корпоративний імідж підприємства серйозний вплив здійснюють ті фактори, сили, суб'єкти позитивної дії, які надають підприємству та його іміджу переваги і які потрібно підтримувати й підсилювати, основними з яких $€$ : персонал, керівник та виробництво. Фактори корпоративного іміджу підприємства та основні шляхи їх підвищення зображено у таблиці 4.

Удосконалення корпоративного іміджу підприємства значною мірою забезпечується вирішенням переліку проблем, середяких найбільш актуальними є на сьогодні нестабільність економічної ситуації в країні, яка характеризується недосконалістю існуючого законодавства, низькою купівельною спроможністю населення, жорсткою податковою політикою, ростом безробіття тощо.

\section{ВИСНОВКИ}

Гострою проблемою в сфері управління корпоративним іміджем $є$ інформаційний дефіцит, що спричиняє брак знань про поточний і прогнозний стан ринку, необхідність високих затрат зусиль і ресурсів для орієнтації на ринку, пошуку платоспроможних покупців і постачальників товарів, неготовність підприємства до зміни попиту, появу на ринку якісної конкурентної продукції. 
Таким чином, можна зробити підсумок, що позитивний корпоративний імідж формується під впливом сукупності чинників зовнішнього та внутрішнього середовища. Він еволюціонує, тобто змінюється залежно від етапу життєвого циклу самого підприємства, а також залежить від роботи керівника та його особистих якостей як менеджера та управлінця.

\section{$\Lambda$ ітература:}

1. Петровский А.В. Теоретическая психология / А.В. Петровский, М.Г.Ярошевский. - М.: Академия, 2001. - 496 с.

2. Котлер Ф. Основы маркетинга / Ф. Котлер; [пер. с англ.]. - М.: Ростинтэр, 1996. — 704 с.

3. Виханский О.С. Стратегическое управление / О.С. Виханский. - М.: Гардарика, 1999. - 292 c.

4. Семенов А.К. Психология и этика менеджмента и бизнеса / А.К. Семенов, Е.А. Маслова. - М.: Информационно-внедренческий центр "Маркетинг", 1999. - 200 с.

5. Орбан Аембрик $\Lambda$. Е. Психологія управління: посібник. - К.: Академвидав, 2003. $568 \mathrm{c.}$

6. Сизоненко В.О. Сучасне підприємництво: довідник. - К.: Знання: Прес, 2007. - 440 с.

7. Бабік Ю. Позитивний імідж підприємства як фактор підвищення конкурентоспроможності / Ю. Бабік / [Електронний ресурс]. Режим доступу: http://dspace.nuft.edu.ua/jspui/ bitstream/123456789/22772/1/61.pdf

8. Краткий политический словарь / В.П. Абаренков, Т.Е. Абова, А.Г. Аверкин и др.; [сост.ред. А.А. Оникова, Н.В. Шишлина]. - 6-е изд., доп. - М.: Политиздат, 1989. - 623 с.

9. Аоти А. Паблисити и паблик рилейшнз.М.: Информационно-издательский дом "Филинъ", 1996 - С. 237.

10. Согачева О.В. Имидж организации как фактор и индикатор ее конкурентоспособности / О.В. Согачева, Е.С. Симоненко // Молодой ученый. - 2014. - № 19. - С. 367-369.

11. Никифоренко В. Роль іміджу в створенні конкурентних переваг підприємства / В. Никифоренко, В. Кравченко [Електронний ресурс]. - Режим доступу: http://dspace.oneu.edu.ua/ jspui/bitstream/pdf

12. Універсальний словник-енциклопедія / Гол. ред. ради академік НАНУ М. Попович. 4-те виА., виправл., доп. - К.: Видавництво "TEKA", 2006. - C. 205

13. Почепцов Г.Г. Имиджелогия / Г.Г. Почепцов. - [2-е изА., испр. и доп.]. - М.: Рефлбук; К.: Ваклер, 2001. - 698 с
14. Гончаренко А. Сколько стоит репутация и как ее вычислить / А. Гончаренко // Бизнес. -2007 . - № 17. - С. 39-41.

\section{References:}

1. Petrovskij, A.V. (2001), Teoreticheskaja psihologija [Theoretical psychology], Akademija, Moscow, Russia.

2. Kotler, F. (1996), Osnovy marketinga [Basics of marketing], Rostintjer, Moscow, Russia.

3. Vihanskij, O.S. (1999), Strategicheskoe upravlenie [Strategic management], Gardarika, Moscow, Russia.

4. Semenov, A.K. (1999), Psihologija i jetika menedzhmenta i biznesa [Psychology and ethics of management and business], Informacionnovnedrencheskij centr "Marketing", Moscow, Russia.

5. Orban, L.E. (2003), Psykholohiia upravlinnia [Psychology of management], Akademvydav, Kyiv, Ukraine.

6. Syzonenko, V.O. (2007), Suchasne pipryiemnytstvo: dovidnyk [Modern business: directory], Znannia: Pres, Kyiv, Ukraine.

7. Babik Yu. (2014), "Positive image of the company as a factor in increasing competitiveness", available at: http://dspace.nuft.edu.ua/ jspui/bitstream/123456789/22772/1/61.pdf (Accessed 10 May 2019).

8. Abarenkov, V.P. Abova, T.E. and Averkin, A.G. (1989), Kratkij politicheskij slovar' [Concise Political Dictionary], Politizdat, Moscow, Russia.

9. Doti, D. (1996), Pablisiti i pablik rilejshnz [Publicity and Public Relations], Informacionno-izdatel'skij dom "Filin", Moscow, Russia.

10. Sogacheva, O.V. (2014), "Image of the organization as a factor and indicator of its competitiveness", Molodoj uchenyj, vol. 19, pp. 367369.

11. Nykyforenko, V. (2017), "The role of the image in creating competitive advantages of the enterprise", available at: http://dspace.oneu.edu.ua/jspui/bitstream/pdf (Accessed 10 May 2019).

12. Popovych, M. (2006), Universal'nyj slovnyk-entsyklopediia [Universal DictionaryEncyclopedia], Vydavnytstvo "TEKA", Kyiv, Ukraine.

13. Pochepcov, G.G. (2001), Imidzhelogija [Imageology], Refl-buk, Moscow, Russia.

14. Goncharenko, A. (2007), "How much is reputation and how to calculate it", Biznes, 17, pp. $39-41$.

Стаття надійшла до редакиіӥ 14.05.2019 p. 